\title{
Influence of winter wheat on soil thermal properties of a Paleudalf**
}

\author{
Samuel I. Haruna* \\ School of Agriculture, College of Basic and Applied Sciences \\ Middle Tennessee State University, Murfreesboro, TN 37132, USA \\ Received November 21, 2018; accepted April 11, 2019
}

\begin{abstract}
Soil thermal properties can influence several soil processes important for crop productivity. This study was conducted to evaluate the influence of cover crops on selected soil physical and thermal properties. The field site was set up using a randomized complete block design with two levels of cover crops (cover crops versus no cover crops). The soil thermal properties measured included thermal conductivity, volumetric heat capacity, and thermal diffusivity. The physical properties of the soil studied included bulk density, volumetric water content, total pore spaces, water-filled pore spaces, air-filled pore spaces, gas diffusion coefficient, and soil pore tortuosity factor. Soil organic carbon was also measured. The results showed that soil organic carbon was $26 \%$ higher under cover crops management compared to no cover crops management. Thermal conductivity and thermal diffusivity were positively correlated with soil bulk density and these properties (soil thermal conductivity and soil thermal diffusivity) were higher under no cover crops management compared with cover crops management probably due to the proximity between soil particles. The volumetric heat capacity was positively correlated with soil organic carbon, with soil organic carbon being higher under cover crops management compared with no cover crops management. Results from the current study show that cover crops can improve soil physical and thermal properties which may benefit crop productivity as corroborated via laboratory measurements.

Keywords: thermal conductivity, volumetric heat capacity, thermal diffusivity, soil organic carbon
\end{abstract}

\section{INTRODUCTION}

Various soil management practices can alter soil properties in several different ways. For example, tillage has been reported to temporarily alleviate soil compaction, increase the availability of soil organic matter and improve the soil temperature and moisture environment for seed germination in early Spring (Stone et al., 1990; Doumbia et al., 2009; He et al., 2010; Haruna et al., 2018a). Similarly,

*Corresponding author e-mail: Samuel.Haruna@mtsu.edu

**This work was supported by Middle Tennessee State University Faculty Research and Creative Activity Committee (FRCAC) grant, index number 221729 (2017-2018) natural prairies have been reported to have a hydraulic conductivity which is higher by one order of magnitude compared to cultivated soils (Fuentes et al., 2004).

Cover crops (CC) have been used to prime the soil for the more economic crops (Troeh et al., 2003). Cover crops have been reported to provide ground coverage (thus reducing erosion) (Haramotto and Gallandt, 2004), increase soil organic matter (Villamil et al., 2006; Haruna et al., 2017) and increase water infiltration (Joyce et al., 2002; Haruna et al., 2018b) as compared with no cover crops (NC). They (CC) have also been reported to increase porosity (Haruna and Nkongolo, 2015) and air-filled porosity at -10 kPa pressure (Abdollah et al., 2014). However, Wagger and Denton (1989) found no differences in soil porosity and saturated hydraulic conductivity when comparing the cultivation of wheat (Triticum aestivum L.) and hairy vetch (Vicia villosa) cover crop to leaving the soil fallow in a strip tillage system. The benefits that may be accrued from cover crop usage depends on, among other factors, the cover crop of choice.

Winter wheat is a winter annual cereal grain that may be grown as a cash grain or used as a cover crop. It can provide some of the benefits of other cereal crops and may also serve as a grazing option in livestock production. When used as a cover crop, winter wheat can reduce soil loss and help maintain topsoil, and recycle nutrients (Kirkegaard et al., 2008). For example, an earlier study in Maryland (Brinsfield and Staver, 1991) showed that winter wheat seeded in September absorbed about $45 \mathrm{~kg} \mathrm{ha}^{-1}$ nitrogen. These phenomena may give rise to cleaner water systems. Furthermore, winter wheat has been reported to produce up to $14,010 \mathrm{~kg} \mathrm{ha}^{-1}$ of biomass (Coale et al.,

(C) 2019 Institute of Agrophysics, Polish Academy of Sciences 
2001). If incorporated into the soil, this biomass may contribute to the build-up of soil organic matter and improve crop productivity.

Crop productivity can also be influenced by soil thermal properties. Soil thermal properties are a measure of heat transport and may be determined through the measurement of soil thermal conductivity $(\lambda)$, volumetric heat capacity $\left(C_{V}\right)$ and soil thermal diffusivity $(D)$ (Hopmans et al., 2002). Thermal conductivity is a measure of the ability of a material to conduct heat, while volumetric heat capacity is a measure of the relationship between thermal energy and the temperature of a material per unit volume (Haruna et al., 2017). Thermal diffusivity is the ratio of $\lambda$ to $C_{V}$ (Shukla, 2014).

Soil thermal properties are influenced by several soil properties including soil mineral composition, soil organic carbon (SOC), volumetric water content $(\theta)$, pore size distributions, and soil bulk density $(\rho b)$. Most of these properties can be influenced by management practices, which may in turn influence soil thermal properties. AbuHamdeh and Reeder (2002) reported that tillage can alter soil thermal properties by increasing $\rho b$ and reducing soil pore spaces and $\theta$. Haruna et al. (2017) reported that cover crops influenced soil thermal properties by increasing SOC and $\theta$ and reducing $\rho b$.

While several studies have quantified the influence of the winter wheat cover crop on SOC, $\rho b$, and $\theta$, to date there have only been very limited studies on the influence of this cover crop on the physical and thermal properties of the soil. Thus, the objective of this study is to evaluate the influence of the winter wheat cover crop on soil physical properties and how they might influence the soil thermal properties. It is hypothesized that the winter wheat cover crop will a) reduce $\rho b$, and increase $\theta$, and SOC, and b) alter various soil heat transport parameters.

\section{MATERIALS AND METHODS}

The research site, about $11 \mathrm{~km}$ northwest of Murfreesboro, is part of the Middle Tennessee State University Farm Laboratories. It is located between latitude $35^{\circ} 53^{\prime} 10^{\prime \prime} \mathrm{N}$ and longitude $86^{\circ} 28^{\prime} 6^{\prime \prime} \mathrm{W}$. The elevation is about 186 $\mathrm{m}$ above sea level. The soil is classified by the USDA as Cumberland silt loam (Fine, mixed, semiactive, thermic Rhodic Paludalfs). Table 1 shows the particle size analysis for the three sampling depths of the study. The research site is 40 ha in size. Prior to the establishment of this research in 2017, the field had a record of two decades of corn (Zea mays L.) and soybean (Glycine max) rotation. During this period, the soil was under no-till management, with a few years of disk ploughing. For this study, the field site was set up using a randomized complete block design with two levels of winter cover crops (CC) vs no cover crops (NC) with three replications. Each plot measured $23.2 \mathrm{~m}$ in length and $10.4 \mathrm{~m}$ in width. It was under no-till management throughout this study.
Table 1. Particle size analysis at various depths for a Cumberland silt loam

\begin{tabular}{lccc}
\hline \multicolumn{1}{c}{ Depth $(\mathrm{cm})$} & Sand & Silt & Clay \\
\cline { 2 - 4 } $0-6$ & & \% by weight & \\
$6-12$ & 9.33 & 65.00 & 25.67 \\
$12-18$ & 8.67 & 66.33 & 25.00 \\
\hline
\end{tabular}

The main crop grown on the field site was corn, planted in May and harvested in October of each year. The winter wheat cover crop was drilled into the standing corn just before harvesting time at a rate of $129 \mathrm{~kg} \mathrm{ha}^{-1}$. It was allowed to grow during the winter months and harvested for hay in April. The average annual precipitation in the area is $1357 \mathrm{~mm}$, with the months of May $(139 \mathrm{~mm})$ and October $(85 \mathrm{~mm})$ recording the highest and lowest precipitation, respectively. The average annual temperature is $14.6^{\circ} \mathrm{C}$, with the months of January $\left(-3.7^{\circ} \mathrm{C}\right)$ and August $\left(32.3^{\circ} \mathrm{C}\right)$ being the coldest and warmest months, respectively. During the vegetative period (October, 2017-April, 2018), the average precipitation was $113.02 \mathrm{~mm}$, with the month of March (152 mm) and the month of October $(78.74 \mathrm{~mm})$ receiving the highest and lowest precipitation, respectively. During this same period, the average atmospheric temperature was $9.27^{\circ} \mathrm{C}$ with the month of January $\left(1.67^{\circ} \mathrm{C}\right)$ and October $\left(16.00^{\circ} \mathrm{C}\right)$ being the coldest and warmest months, respectively.

Intact soil samples were collected using a core sampler at the site in April 2018, about 2 weeks before CC harvest. The core measured $6 \mathrm{~cm}$ long and $5.5 \mathrm{~cm}$ wide, with a $0.1 \mathrm{~cm}$ thick wall. Intact soil cores were collected from the non-trafficked inter-row areas at $0-6 \mathrm{~cm}, 6-12 \mathrm{~cm}$ and $12-18 \mathrm{~cm}$ depths. The soil cores were labelled, trimmed, top and bottom covered with plastic disks, sealed in plastic bags and transported to the laboratory, with minimal disturbance. The samples were stored in a refrigerator at $4^{\circ} \mathrm{C}$ until laboratory measurements were conducted.

A push probe was used to collect soil samples from the aforementioned soil depths. These samples were air dried, sieved and sent to a commercial laboratory for organic carbon analysis. Soil organic carbon was analysed using the combustion method.

Soil samples were taken from cold storage and weighed (without the plastic bags and disks). Soil thermal properties were then measured using the KD2 (Decagon Devices) dual-probe heat-pulse sensor. Several researchers have used a similar probe (e.g., Bristow et al., 1993; Kluitenberg et al., 1995; Dahiya et al., 2007; Adhikari et al., 2014; Haruna et al., 2017). Before measurement, the probe was calibrated and its accuracy was tested using performance verification standards. The probe was inserted vertically into the soil, ensuring proper soil contact and avoiding core walls. The thermal properties measured included $\lambda, C_{V}$, and $D$.

After the thermal properties were measured, the soil was oven-dried at $105^{\circ} \mathrm{C}$ for $48 \mathrm{hrs}$. The oven-dried samples were weighed. The soil was then ground and passed through a $2-\mathrm{mm}$ sieve. The $<2 \mathrm{~mm}$ particles were used 
for soil particle size determination using the pipette method (Gee and Or, 2002). Bulk density was calculated using the core method (Grossman and Reinsch, 2002). Volumetric water content $(\theta)$, total pore spaces $(T P S)$, water-filled pore spaces (WFPS), air-filled pore spaces (AFPS), the gas diffusion coefficient $(D s / D o)$, and the soil pore tortuosity factor $(\tau)$ were calculated using the methods of Nkongolo et al. (2010) and Haruna and Nkongolo (2015).

A test of normality was conducted for $\rho b$, SOC, $\theta, T P S$, $W F P S, A F P S, D s / D o$, and $\tau$ using the Anderson-Darling test at $\mathrm{P}=0.05$ in SAS version 9.4 (SAS Institute, 2015). The normality test showed that all data were normally distributed. An Analysis of Variance (ANOVA) was conducted using the PROC GLM procedure. Means and differences among means for the measured parameters were determined using PROC MEANS. The single degree of freedom contrast for the two treatments was divided into ' $\mathrm{CC}$ vs $\mathrm{NC}$ '. ANOVA was also conducted to determine the treatment $X$ depth interaction on the aforementioned soil physical and thermal properties. The PROC CORR procedure was used to determine the initial relationships between $\lambda, C_{b}, D, \rho b$, $\theta$, SOC, and TPS. The statistical differences were analysed at the $\mathrm{p} \leq 0.05$ probability level.

\section{RESULTS AND DISCUSSION}

Results show the significant effect of sampling depth on soil bulk density $(\rho b)$ and total pore spaces (TPS) (Table 2). Averaged over all treatments, $\rho b$ was significantly lower at the $0-6 \mathrm{~cm}$ depth compared with other depths. Although not significant, $\rho b$ was numerically lower under CC management compared with $\mathrm{NC}$ management. Soil bulk density was lowest at the $0-6 \mathrm{~cm}$ depth of cover crops $\left(1.16 \mathrm{~g} \mathrm{~cm}^{-3}\right)$, probably due to the activities of the cover crop roots. Similarly, TPS was significantly higher in the $0-6 \mathrm{~cm}$ depth as compared to other sampling depths. The total pore space was numerically greater under $\mathrm{CC}$ management as compared to NC management and also higher at the $0-6 \mathrm{~cm}$ depth of CC management.

Soil organic carbon $(\mathrm{SOC})$ was significantly $(\mathrm{p}=0.024)$ higher under $\mathrm{CC}$ management compared with NC management (Table 3). Soil organic matter under CC management was $29.56 \mathrm{~g} \mathrm{~kg}^{-1}$, about $26 \%$ greater than it was under $\mathrm{NC}$ management. This is probably due to the decomposition of the below ground biomass of winter wheat. Sainju et al. (2002) and Villamil et al. (2006) reported greater SOC under CC management as compared with $\mathrm{NC}$ management. Sainju et al. (2002) reported a $12 \%$ increase, while Villamil et al. (2006) reported a 9\% increase. Conversely, Lal et al. (1991) reported a minimal change or no change in SOC content due to CC. Wander and Traina (1996) suggested that the reason for not detecting any SOC change could be due to soil heterogeneity, which occurs naturally.

Volumetric water content $(\theta)$ was significantly higher at the $0-6 \mathrm{~cm}$ depth compared to other depths (Table 3). This is in agreement with the $\rho b$ and TPS results. As a result of lower $\rho b$ and higher TPS under CC management, $\theta$ was slightly higher under $\mathrm{CC}$ management compared with $\mathrm{NC}$ management. There was also a significant $(p=0.034)$ interaction between $\theta$ and the sampling depth. Volumetric water content was greater at the $0-6 \mathrm{~cm}$ and $6-12 \mathrm{~cm}$ depths of $\mathrm{CC}$ management compared with $\mathrm{NC}$ management. However, at the $12-18 \mathrm{~cm}$ depth, $\theta$ was greater in $\mathrm{NC}$ as compared with $\mathrm{CC}$ (Fig. 1). The higher $\theta$ at the $12-18 \mathrm{~cm}$ depth under NC management could be due to soil heterogeneity at this depth.

Table 2. Effects of cover crops and sampling depth on selected soil physical properties

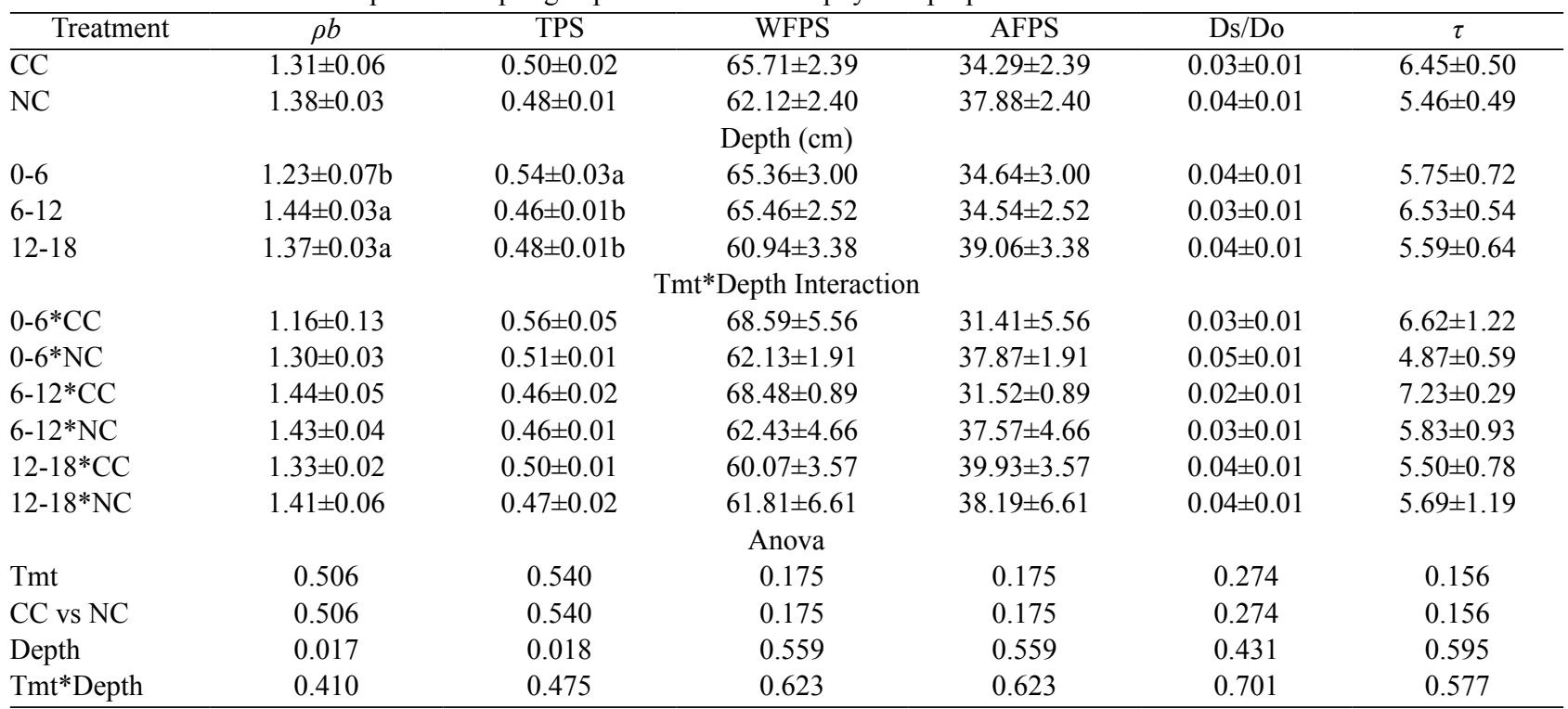

Means followed by a different letter in the same treatment and sampling depth are statistically significant at the 0.05 probability level. $\rho b$ - soil bulk density $\left(\mathrm{g} \mathrm{cm}^{-3}\right)$; TPS - total pore spaces $\left(\mathrm{cm}^{3} \mathrm{~cm}^{-3}\right)$; WFPS - water-filled pore spaces (\%); AFPS - air-filled pore spaces (\%); Ds/Do - relative gas diffusion coefficient $\left(\mathrm{m}^{2} \mathrm{~s}^{-1} \mathrm{~m}^{-2} \mathrm{~s}\right) ; \tau$ - pore tortuosity factor $\left(\mathrm{m} \mathrm{m}^{-1}\right)$; Tmt - treatment. 
Table 3. Effects of cover crop and sampling depth on soil organic carbon, volumetric water content and soil thermal properties

\begin{tabular}{|c|c|c|c|c|c|}
\hline Treatment & SOC & $\theta$ & $\mathrm{C}_{\mathrm{V}}$ & $\lambda$ & $\mathrm{D}$ \\
\hline$\overline{\mathrm{CC}}$ & $29.56 \pm 0.44 a$ & $0.32 \pm 0.02$ & $3.12 \pm 0.02 \mathrm{a}$ & $1.24 \pm 0.09$ & $0.40 \pm 0.03 b$ \\
\hline $\mathrm{NC}$ & $21.78 \pm 0.31 b$ & $0.31 \pm 0.01$ & $2.43 \pm 0.06 \mathrm{~b}$ & $1.38 \pm 0.07$ & $0.57 \pm 0.04 \mathrm{a}$ \\
\hline \multicolumn{6}{|c|}{ Depth $(\mathrm{cm})$} \\
\hline $0-6$ & $38.83 \pm 0.39 \mathrm{a}$ & $0.35 \pm 0.02 \mathrm{a}$ & $2.88 \pm 0.13 \mathrm{a}$ & $1.10 \pm 0.06 b$ & $0.39 \pm 0.04 b$ \\
\hline $6-12$ & $21.33 \pm 0.23 b$ & $0.30 \pm 0.01 b$ & $2.79 \pm 0.15 \mathrm{a}$ & $1.48 \pm 0.09 \mathrm{a}$ & $0.54 \pm 0.04 \mathrm{a}$ \\
\hline $12-18$ & $16.83 \pm 0.19 \mathrm{c}$ & $0.29 \pm 0.01 \mathrm{~b}$ & $2.66 \pm 0.20 \mathrm{~b}$ & $1.34 \pm 0.08 \mathrm{a}$ & $0.52 \pm 0.06 \mathrm{a}$ \\
\hline \multicolumn{6}{|c|}{ Tmt*Depth Interaction } \\
\hline $0-6 * \mathrm{CC}$ & $45.00 \pm 0.55$ & $0.38 \pm 0.01 \mathrm{a}$ & $3.16 \pm 0.04$ & $0.97 \pm 0.03$ & $0.31 \pm 0.01$ \\
\hline $0-6 * \mathrm{NC}$ & $32.67 \pm 0.30$ & $0.31 \pm 0.01 \mathrm{~b}$ & $2.60 \pm 0.02$ & $1.23 \pm 0.05$ & $0.47 \pm 0.02$ \\
\hline $6-12 * \mathrm{CC}$ & $24.00 \pm 0.36$ & $0.30 \pm 0.01 \mathrm{~b}$ & $3.11 \pm 0.02$ & $1.51 \pm 0.14$ & $0.48 \pm 0.05$ \\
\hline $6-12 * \mathrm{NC}$ & $18.67 \pm 0.24$ & $0.30 \pm 0.02 b$ & $2.46 \pm 0.07$ & $1.45 \pm 0.16$ & $0.59 \pm 0.07$ \\
\hline $12-18 * \mathrm{CC}$ & $19.67 \pm 0.26$ & $0.28 \pm 0.01 \mathrm{~b}$ & $3.10 \pm 0.01$ & $1.24 \pm 0.09$ & $0.40 \pm 0.03$ \\
\hline $12-18 * \mathrm{NC}$ & $14.00 \pm 0.20$ & $0.31 \pm 0.03 b$ & $2.22 \pm 0.08$ & $1.45 \pm 0.11$ & $0.65 \pm 0.03$ \\
\hline \multicolumn{6}{|c|}{ Anova } \\
\hline Tmt & 0.024 & 0.335 & 0.001 & 0.416 & 0.058 \\
\hline $\mathrm{CC}$ vs $\mathrm{NC}$ & 0.024 & 0.335 & 0.001 & 0.416 & 0.058 \\
\hline Depth & $<0.001$ & 0.009 & 0.001 & 0.016 & 0.010 \\
\hline Tmt*Depth & 0.106 & 0.034 & 0.130 & 0.298 & 0.230 \\
\hline
\end{tabular}

Means followed by a different letter in the same treatment and sampling depth are statistically significant at the 0.05 probability level. SOC - soil organic carbon $\left(\mathrm{g} \mathrm{kg}^{-1}\right) ; \theta$ - volumetric water content $\left(\mathrm{cm}^{3} \mathrm{~cm}^{-3}\right) ; \mathrm{C}_{\mathrm{V}}$ - volumetric heat capacity $\left(\mathrm{MJ} \mathrm{m}^{-3} \mathrm{~K}^{-1}\right) ; \lambda-$ thermal conductivity $\left(\mathrm{W} \mathrm{m}^{-1} \mathrm{~K}^{-1}\right)$; $\mathrm{D}$ - thermal diffusivity $\left(\mathrm{mm}^{2} \mathrm{~s}^{-1}\right)$.

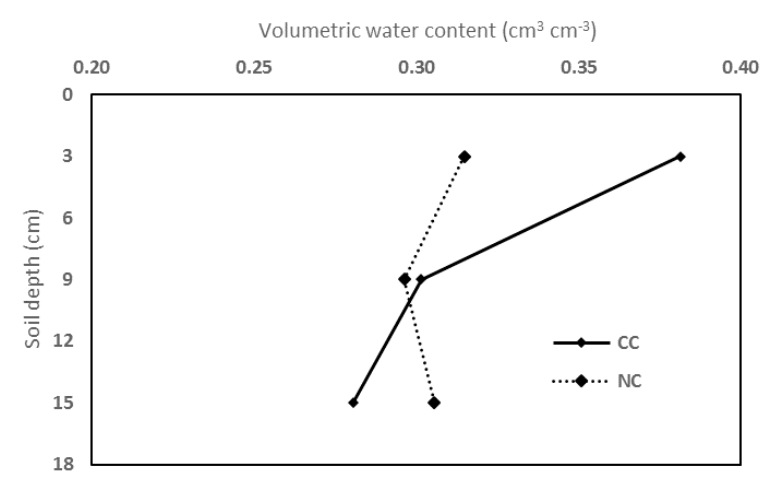

Fig. 1. Effect of cover crop $X$ sampling depth interaction on volumetric water content. $\mathrm{CC}$ - cover crop; $\mathrm{NC}$ - no cover crop.

Water filled pore spaces was slightly higher under CC management as compared to $\mathrm{NC}$ management. However, $A F P S$ followed an inverse trend, probably due to the inverse relationship between soil air and soil water content (Table 2). Haruna and Nkongolo (2015) reported a similar trend after three years of cereal rye (Secale cereale) cover crop management. Conversely, Cercioglu et al. (2018) reported a higher density of air-filled pore spaces under CC management compared with NC management in a computed tomography study. However, in contrast to the single cover crop species used in the current study, these researchers (Cercioglu et al., 2018) used a group of three cover crops.

The activities of living roots may alleviate soil compaction, and open pore spaces. When these roots decay, in addition to above ground biomass incorporation, they can also increase SOC, which may further improve the physical properties of the soil. This supports the first hypothesis.
Thus, cover crops may be used to improve some soil physical properties and this has the potential to improve water infiltration, environmental sustainability (Haruna et al., 2018 b) and crop productivity.

Averaged over all three depths, the results from the current study show that management had a significant effect on volumetric heat capacity $\left(C_{V}\right)(\mathrm{p}=0.001)$ and thermal diffusivity $(D)(\mathrm{p}=0.058)$ (Table 3$)$. Under CC management, $C_{V}$ was $3.12 \mathrm{MJ} \mathrm{m}^{-3} \mathrm{~K}^{-1}$, about $28 \%$ greater than under $\mathrm{NC}$ management. The $C_{V}$ of the soil is influenced by several soil components; soil water content, SOC, and clay minerals. The $C_{V}$ values of water $\left(4.18 \mathrm{MJ} \mathrm{m}^{-3} \mathrm{~K}^{-1}\right)$ and organic carbon $\left(2.50 \mathrm{MJ} \mathrm{m}^{-3} \mathrm{~K}^{-1}\right)$ are both relatively higher than that of clay minerals $\left(1.20 \mathrm{MJ} \mathrm{m}^{-3} \mathrm{~K}^{-1}\right.$ ) (Bristow, 2002). Higher $\theta$ and SOC under $\mathrm{CC}$ management might be directly responsible for the higher $C_{V}$. Furthermore, soil colloids (e.g. SOC) also have a larger surface area that can adsorb more water. This may further increase the $C_{V}$ of the soil. Volumetric heat capacity was highest at the $0-6 \mathrm{~cm}$ depth and decreased with an increase in sample depth. This is in agreement with the SOC and $\theta$ results (Table 3 ).

The higher volumetric heat capacity $\left(C_{V}\right)$ under CC management in the current study suggests that cover crops like winter wheat can increase the soil heat buffering capacity. Thus, CC can help maintain soil temperature for a longer time during the growing season by reducing water evaporation and increasing SOC. This may be more beneficial in warmer climates where very drastic daily and annual soil temperatures have the potential to threaten soil microbial activity, root growth and overall crop productivity. Furthermore, the inclusion of CC into crop rotation may improve the sustainability of crop productivity in a changing global climate. 
Thermal conductivity $(\lambda)$ was slightly higher under NC management as compared with $\mathrm{CC}$ management (Table 3). The higher $\lambda$ values in NC are probably due to an increase in $\rho b$ and a decrease in SOC. An increase in $\rho b$ increases area of contact between soil particles. Since the $\lambda$ of clay minerals (2.9 $\left.\mathrm{W} \mathrm{m}^{-1} \mathrm{~K}^{-1}\right)$ is higher than that of SOC $\left(0.25 \mathrm{~W} \mathrm{~m}^{-1} \mathrm{~K}^{-1}\right)$, soils with higher $\rho b$ have been reported to have a higher $\lambda$ (AbuHamder and Reeder, 2000; Haruna et al., 2017). The results of this study suggest that $\mathrm{NC}$ may be a better management option for lengthening the growing season in cooler climates where frozen soils limit crop production. The results also show a significant sampling depth effect on $\lambda$. Thermal conductivity was lowest at the 0-6 cm depth. It $(\lambda)$ was highest at the 6-12 $\mathrm{cm}$ depth. This is in agreement with the $\rho b$ results.

Thermal diffusivity $(D)$ values under CC management was $0.40 \mathrm{~mm}^{2} \mathrm{~s}^{-1}$, about $30 \%$ lower than under NC management. Since $D$ is the ratio of $\lambda$ to $C_{V}$, this suggests that $\mathrm{NC}$ may cause a higher rate of water evaporation from soil, leading to a further decrease in $\theta$ under NC management. Thermal diffusivity was significantly influenced by the soil sampling depth. Thermal diffusivity was significantly lower at the 0-6 cm depth and highest at the 6-12 cm depth.

The results from the current study show significant correlations between some soil physical properties and soil thermal properties (Table 4 ). The thermal conductivity $(\lambda)$ was positively correlated with the soil bulk density $(\rho b)(\mathrm{r}=0.71$; $\mathrm{p}=0.001)$. However, thermal conductivity was significantly negatively correlated with SOC, $\theta$, and TPS. The volumetric heat capacity $\left(C_{V}\right)$ was significantly positively correlated with SOC $(\mathrm{r}=048 ; \mathrm{p}=0.042)$. Thermal diffusivity $(D)$ was positively correlated with $\rho b(\mathrm{r}=0.64 ; \mathrm{p}=0.004)$ and negatively correlated with SOC, $\theta$, and TPS (Table 4).

The significant correlation between $\rho b$ and thermal properties shows that the soil can warm up quickly, and to a deeper depth under NC crop management. This is because as $\rho b$ increases, the number of pore spaces is reduced, thus increasing the area of contact between soil particles. An increase in SOC and $\theta$ increased $C_{V}$, the soil heat buffering capacity. Similarly, Abu-Hamdeh and Reeder (2000) noted a significantly lower $\lambda$ with the addition of SOC in a laboratory study.

The correlation results showed that $\mathrm{CC}$ management appears to be the best option to conserve soil moisture and reduce thermal conductance. However, thermal conductance is also dependent on the amount of solar energy reaching the soil surface. Since NC management produces little vegetation and residue cover in the spring season, the amount of solar energy reaching the soil surface may be higher. This will further increase the rate of water evaporation, increase the activity of aerobic microorganisms, deplete SOC and further increase thermal conductivity. Laboratory results from the current study suggest that, in a world facing growing concern about the influence of climate change on crop productivity, cover crops may act as a buffer against extreme soil temperature change. This could improve microbial activity, nutrient availability and overall crop productivity.

Table 4. Pearson's correlations of select soil physical properties and thermal properties at all measured depths

\begin{tabular}{|c|c|c|c|c|c|c|c|}
\hline Parameter & $\lambda$ & $\mathrm{C}_{\mathrm{V}}$ & D & $\rho b$ & SOC & $\theta$ & TPS \\
\hline$\lambda$ & 1 & & & & & & \\
\hline $\mathrm{C}_{\mathrm{V}}$ & $\begin{array}{c}-0.35 \\
(0.1557) \dagger\end{array}$ & 1 & & & & & \\
\hline D & $\begin{array}{c}0.85 \\
(<0.0001)\end{array}$ & $\begin{array}{c}-0.78 \\
(0.0001)\end{array}$ & 1 & & & & \\
\hline$\rho b$ & $\begin{array}{c}0.71 \\
(0.0001)\end{array}$ & $\begin{array}{c}-0.34 \\
(0.1664)\end{array}$ & $\begin{array}{c}0.64 \\
(0.0041)\end{array}$ & 1 & & & \\
\hline SOC & $\begin{array}{c}-0.56 \\
(0.0156)\end{array}$ & $\begin{array}{c}0.48 \\
(0.0416)\end{array}$ & $\begin{array}{c}-0.63 \\
(0.0052)\end{array}$ & $\begin{array}{c}-0.73 \\
(0.0007)\end{array}$ & 1 & & \\
\hline$\theta$ & $\begin{array}{c}-0.49 \\
(0.0376)\end{array}$ & $\begin{array}{c}0.20 \\
(0.4327)\end{array}$ & $\begin{array}{c}-0.41 \\
(0.0918)\end{array}$ & $\begin{array}{c}-0.60 \\
(0.0082)\end{array}$ & $\begin{array}{c}0.71 \\
(0.0009)\end{array}$ & 1 & \\
\hline TPS & $\begin{array}{c}-0.70 \\
(0.0012)\end{array}$ & $\begin{array}{c}0.33 \\
(0.1818) \\
\end{array}$ & $\begin{array}{c}-0.63 \\
(0.0049) \\
\end{array}$ & $\begin{array}{c}-0.99 \\
(<0.0001)\end{array}$ & $\begin{array}{c}0.72 \\
(0.0008)(\end{array}$ & $\begin{array}{c}0.59 \\
(0.0098)\end{array}$ & 1 \\
\hline
\end{tabular}

$\dagger \mathrm{p}$ values in parenthesis; $\mathrm{p}<0.05$ indicates significant correlation. $\lambda$ - thermal conductivity; $C_{V}-$ volumetric heat capacity; $D$ - thermal diffusivity; $\rho \mathrm{b}$ - soil bulk density; $\mathrm{SOC}$ - soil organic carbon; $\theta$ - volumetric water content; TPS - total pore spaces.

\section{CONCLUSIONS}

1. Soil bulk density and total pore spaces were numerically lower, while soil organic carbon was significantly higher under cover crop management as compared with no cover crop management, this was probably due to root density. This lead to a numerical increase in water-filled pore spaces and volumetric water content.

2. The volumetric water content was approximately $3 \%$ higher under cover crop management as compared with no cover crop management.

3 . The volumetric heat capacity was positively correlated with soil organic carbon and volumetric water content and it (volumetric heat capacity) was $28 \%$ higher under cover crop management as compared with no cover crop management.

4. The thermal conductivity and thermal diffusivity were both positively correlated with $\rho b$ and they were $11 \%$ and $30 \%$ higher respectively, under no cover crop management as compared with cover crop management. This was probably due to the increased contact area between soil particles as a result of lower plant root density.

5. Results from the current study suggest that, under laboratory conditions, winter wheat improved selected soil physical and thermal properties and this may enhance crop productivity.

Conflict of interest: The author declare that there are no conflicts of interest.

Compliance with ethical requirements: This study does not contain any experiment involving human or animal subjects. 


\section{REFERENCES}

Abdollahi L., Munkholm L.J., and Garbout A., 2014. Tillage system and cover crop effects on soil quality: II. Pore characteristics. Soil Sci Soc Am J., 78, 271-279. https://doi. org/10.2136/sssaj2013.07.0302

Abu-Hamdeh H.N., and Reeder R.C., 2000. Soil thermal conductivity: Effects of density, moisture, salt concentrations, and organic matter. Soil Sci. Soc. Am. J., 64, 1285-1290. https://doi.org/10.2136/sssaj2000.6441285x

Adhikari P., Udawatta R.P., and Anderson S.H., 2014. Soil thermal properties under prairies, conservation buffers, and corn-soybean land use systems. Soil Sci. Soc. Am. J., 78, 1977- 1986. https://doi.org/10.2136/sssaj2014.02.0074

Brinsfield R., and Staver K., 1991. Role of cover crops in reduction of cropland nonpoint source pollution. Final report to USDA-SCS, Cooperative Agreement \#25087.

Bristow K.L., 2002. Thermal conductivity. In: Methods of soil analysis (Eds J.H. Dane, G.C. Topp). Soil Science Society of America. Madison, WI. USA.

Bristow K.L., Campbell G.S., and Calissendorff C., 1993. Test of a heat-pulse probe for measuring changes in soil water content. Soil Sci. Soc. Am. J., 57, 930-934. https://doi. org/10.2136/sssaj1993.03615995005700040008x

Cercioglu M., Anderson S.H., Udawatta R.P., and Haruna S.I., 2018. Effects of cover crop and biofuel crop management on computed tomography-measured pore parameters. Geoderma, 319, 80-88. https://doi.org/10.1016/j.geoderma. 2018.01.005

Coale F.J., Costa J.M., Bollero G.A., and Schlosnagle S.P., 2001. Small grain winter cover crops for conservation of residual soil nitrogen in the mid-Atlantic Coastal Plain. Am. J. Alt. Agri., 16, 66-72. https://doi.org/10.1017/S08891 89300008948

Dahiya R., Ingwersen J., and Streck T., 2007. The effect of mulching and tillage on the water and temperature regimes of a loess soil: Experimental findings and modeling. Soil Till. Res., 96, 52- 63. https://doi.org/10.1016/j.still.2007.02.004

Doumbia M., Jarju A., Sène M., Traoré K., Yost R., Kablan R., Brannan K., Berthe A., Yamoah C., Querido A., and Traoré P.C., 2009. Sequestration of organic carbon in West African soils by Aménagement en Courbes de Niveau. Agron. Sustain. Develop., 29, 267-275. https://doi.org/ 10.1051/agro/2008041

Fuentes J.P., Flury M., and Bezdicek D.F., 2004. Hydraulic properties in a silt loam soil under natural prairie, conventional till, and no-till. Soil Sci. Soc. Am. J., 68, 1679-1688. https://doi.org/10.2136/sssaj2004.1679

Gee G.W., and Or D., 2002. Particle-size analysis. In: Methods of soil analysis (Eds J.H. Dane, G.C. Topp). Soil Science Society of America, Madison, WI. USA.

Grossman R.B., and Reinsch T.G., 2002. Bulk density and linear extensibility. In: Methods of soil analysis (Eds J.H. Dane, G.C. Topp). Soil Science Society of America, Madison, WI. USA. https://doi.org/10.2136/sssabookser5. 4.c9

Haramoto E.R., and Gallandt E.R., 2004. Brassica cover cropping for weed management: A review. Renew. Agric. Food Syst., 19, 187-198. https://doi.org/10.1079/RAFS200490

Haruna S.I., and Nkongolo N.V., 2015. Effects of tillage, rotation and cover crop on the physical properties of a silt-loam soil. Int. Agrophys., 29, 137-145. https://doi.org/10.1515/ intag-2015-0030
Haruna S.I., Anderson S.H., Nkongolo, N.V., Reinbott, T., and Zaibon, S., 2017. Soil thermal properties influenced by perennial biofuel and cover crop management. Soil Sci. Soc. Am. J., 81, 1147-1156. https://doi.org/10.2136/sssaj 2016.10.0345

Haruna S.I., Anderson S.H., Nkongolo N.H., and Zaibon S., 2018a. Soil hydraulic properties: Influence of tillage and cover crops. Pedosphere., 28; 430-442. https://doi. org/10.1016/S1002-0160(17)60387-4

Haruna S.I., Anderson S.H., Nkongolo N.V., Eivazi F., and Zaibon S., 2018b. In situ infiltration influenced by cover crop and tillage management. J. Soil Water Conserv., 73, 164-172. https://doi.org/10.2489/jswc.73.2.164

He J., Li H., Kuhn N.H., Wang Q., and Zhang X., 2010. Effect of ridge tillage, no-tillage, and conventional tillage on soil temperature, water use, and crop performance in cold and semi-arid areas in Northeast China. Soil Res., 48, 737-744. https://doi.org/10.1071/SR09155

Hopmans J.W., Šimunek J., and Bristow K.L., 2002. Indirect estimation of soil thermal properties and water flux using heat pulse probe measurements: Geometry and dispersion effects. Water Resour. Res., 38, 71-714. https://doi.org/10. 1029/2000WR000071

Joyce B.A., Wallender W.W., Mitchell J.P., Huyck L.M., Temple S.R., Brostrom P.N., and Hsiao T.C., 2002. Infiltration and soil water storage under winter cover cropping in California's Sacramento Valley. Trans ASAE., 45, 315-326. https://doi.org/10.13031/2013.8526

Kirkegaard J., Christen O., Krupinsky J., and Layzell D., 2008. Break crop benefits in temperate wheat production. Field Crops Res. 107, 185-195. https://doi.org/10.1016/j. fcr.2008.02.010

Kluitenberg G.J., Bristow K.L., and Das B.S., 1995. Error analysis of the heat pulse method for measuring soil heat capacity, diffusivity and conductivity. Soil Sci. Soc. Am. J., 59, 719-726. https://doi.org/10.2136/sssaj1995.0361599500 $5900030013 x$

Lal R., Regnier E., Eckert D.J., Edwards W.M., Hammond R., 1991. Expectations of cover crops for sustainable agriculture. In: Cover crops for clean water (Ed W.L. Hargrove). Soil and Water Conservation Society of America, Ankeny, IA, USA.

Nkongolo N.V., Hatano R., and Kakembo V., 2010. Diffusivity models and greenhouse gases fluxes from a forest, pasture, grassland and corn field in Northern Hokkaido, Japan. Pedosphere, 20, 747-760. https://doi.org/10.1016/S1002 $-0160(10) 60065-3$

Sainju U.M., Singh B.P., and Whitehead W.F., 2002. Long-term effects of tillage, cover crops, and nitrogen fertilization on organic carbon and nitrogen concentrations in sandy loam soils in Georgia, USA. Soil Till. Res., 63, 167-179. https:// doi.org/10.1016/S0167-1987(01)00244-6

SAS Institute, 2015. Base SAS 9.4 Procedures Guide. SAS Institute, Cary, NC, USA.

Shukla M.K., 2014. Soil physics: An introduction. CRC Press, Boca Raton, FL, USA.

Stone J.A., Vyn T.J., and Clarke N.D., 1990. Ridge tillage for corn and soybean production on clay and clay-loam soils in southwestern Ontario-a review. Soil Till. Res., 18, 219-230. https://doi.org/10.1016/0167-1987(90)90062-I 
Villamil M.B., Bollero G.A., Darmody R.G., Simmons F.W., and Bullock D.G., 2006. No-Till Corn/Soybean Systems Including Winter Cover Crops. Soil Sci. Soc. Am. J., 70, 1936-1944. https://doi.org/10.2136/sssaj2005.0350

Wagger M.G., and Denton H.P., 1989. Influence of cover crop and wheel traffic on soil physical properties in continuous no-till corn. Soil Sci. Soc. Am. J., 53, 1206-1210. https:// doi.org/10.2136/sssaj1989.03615995005300040036x

Wander M.M., and Traina S.J., 1996. Organic fractions from organically and conventionally managed soils: I. Carbon and nitrogen distribution. Soil Sci. Soc. Am. J., 60, 1081-1087. https://doi.org/10.2136/sssaj1996.036159950060000 40017x 